\title{
Impact of Mulching and Sources of Fertilizer on Yield and Nutrient Uptake in Red Chilli (Capsicum annuum L.) under Drip Irrigation
}

\author{
G. Chandramohan Reddy ${ }^{1 *}$, S.S. Hebbar ${ }^{2}$, A.K. Nair ${ }^{2}$, H.B. Raghupathy ${ }^{3}$, \\ A.P. Mallikarjuna Gowda ${ }^{1}$ and K. Umesha ${ }^{1}$
}

${ }^{1}$ Department of Spices, Plantation, Medicinal and Aromatic Crops, College of Horticulture, GKVK University of Horticultural sciences Campus, Bangalore, Karnataka -560065, India

${ }^{2}$ Division of Vegetable science, Indian Institute of Horticulture Research, Hessaraghatta, Bangalore, Karnataka-560089, India

${ }^{3}$ Division of Soil Science and Agricultural chemistry, Indian Institute of Horticulture

Research, Hessaraghatta, Bangalore, Karnataka-560089, India

*Corresponding author

\section{A B S T R A C T}

Keywords

Chilli, Fertigation,

Mulching, Yield

and Nutrient uptake

Article Info

Accepted:

12 December 2017

Available Online:

10 January 2018
A field study was carried out on a red loamy soils of Bangalore for year (2015-2016) to study the effect of different fertilizer sources and mulching on yield, nutrient uptake in hybrid chilli cultivar Arka meghana (Capsicum annuum L.). The trial included nine treatments comprising varying rates and sources of fertilizers, tested with or without mulching. Application of recommended dose of fertilizer (180:120:180 kg NPK/ha) through fertigation using water-soluble fertilizers resulted in higher higher number fruits (142) per plant, fruit length $(11.3 \mathrm{~cm})$, fruit girth $(4.75 \mathrm{~cm})$, fruit weight $(1.29 \mathrm{~g})$, fruit yield per plant $(184.11 \mathrm{~g})$, fruit yield per hectare $\left(5.03 \mathrm{t} \mathrm{ha}^{-1}\right)$, followed by $100 \%$ normal fertilizers fertigation with mulching. Application of fertilizers both water soluble as well as normal fertilizers through fertigation with mulching recorded higher uptake of N, P and K at compared to RDF soil application without mulching.

\section{Introduction}

Among the spice crops of India Chilli (Capsicum annuum L.), a member of Solanaceae family is an important one. Being introduced by Portuguese in 17th century, now the crop is grown all over India, especially in Andhra Pradesh, Karnataka, Tamil Nadu and Maharashtra, account for 3/4 of the total area besides Madhya Pradesh, West Bengal,
Punjab, Bihar and Rajasthan. Dried fruits are used to make universal curry powder and curry paste. The fruit of chilli contains carbohydrates, vitamin A and vitamin C. Fresh green and ripe chillies are used to make all kinds of pickles, different sauces and paste. The red colour, capsanthin is used in high quality cosmetic preparations like lipstick. The essential oil, oleoresin is used in the food and beverage industries. The pungency is due to an 
active principle "Capsaicin" an alkaloid present in pericarp and placenta, which are a digestive stimulant and an important ingredient of daily diet and a cure for many rheumatic problems (Chandini Raj et al., 2016).

The fertilizers are power full crop management tools and can make effective contribution to crop production only when all other production factors are in reasonable balance and receive appropriate attention. Number of investigations has shown that there is a definite and nearly constant requirement of NPK for production of high yielding hybrids of crop. The low use efficiency of NPK is because of various reasons such as volatilization, denitrification, surface run off, leaching losses and ammonia fixation in soil for phosphorus. Fertigation is an effective means of controlling, timing and placement of fertilizers and improving fertilizer use efficiency by reducing losses through leaching, volatilization and fixation in the soil to less available forms (Papadopoulous, 1994).

Mulching reduces the runoff and soil loss, minimize the weed infestation, checks the evaporation of water thus facilitates for more retention of soil moisture and improve the physical, chemical and biological properties of soil as it adds nutrients to soil and ultimately enhance the growth and yield of crops and profits (Hatami, 2012). Hence, the present study was conducted to determine the effect of different source of fertilizers and mulching on yield and nutrient uptake of chilli

\section{Materials and Methods}

Afield experiment was conducted during Kharif season 2015-16 at the Division of vegetable crops, IIHR-Hessaraghatta, Bangalore in randomized block design comprising of nine treatments with three replicate. The treatment details are
$\mathrm{T}_{1}$ : Fertigation with water soluble fertilizers (Urea, 19:19:19 and $\mathrm{KNO}_{3}$ ) @ 100\% RDF and polyethylene mulching

$\mathrm{T}_{2}$ : Fertigation with water soluble fertilizers (Urea, 19:19:19 and $\mathrm{KNO}_{3}$ ) @ 75\% RDF and polyethylene mulching

$\mathrm{T}_{3 \text { : Fertigation with water soluble fertilizers }}$ (Urea, 19:19:19 and $\mathrm{KNO}_{3}$ ) @ 100\% RDF and without mulching

$\mathrm{T}_{4}$ : Fertigation with water soluble fertilizers (Urea, 19:19:19 and $\mathrm{KNO}_{3}$ ) @ 75\% RDF and without mulching

$\mathrm{T}_{5}$ : Fertigation with normal fertilizers (Urea, DAP and MOP) @ 100\% RDF and polyethylene mulching

$\mathrm{T}_{6}$ : Fertigation with normal fertilizers (Urea, DAP and MOP)@100\% RDF and without mulching

$\mathrm{T}_{7}$ : N\&K fertigation with WSF (Urea and $\mathrm{KNO}_{3}$ ), soil application of $\mathrm{P}$ fertilizer (SSP) @ 100\% RDF and mulching

$\mathrm{T}_{8}$ : N\&K fertigation with WSF (Urea and $\mathrm{KNO}_{3}$ ), soil application of $\mathrm{P}$ fertilizer (SSP) @ 100\% RDF and without mulching

$\mathrm{T}_{9}$ : Control - Drip irrigation, non-mulched and soil application of NPK fertilizers (Urea, SSP and MOP) @ 100\% RDF

Bicoloured (30 micron) polythene sheet were spread over the soil surface for each treatment very close to the ground surface. The recommended dose of NPK (18 0:120:180 kg $\mathrm{ha}^{-1}$ ) fertilizers applied as per the treatments imposed. Fertigation was done in weekly intervals starting from 21 DAP up to 150 DAP. The soil of the experiment site was had pH 5.5, E.C. $0.24 \mathrm{dsm}^{-1}$, available N 303.18 $\mathrm{kg} \mathrm{ha}^{-1} \mathrm{P}_{2} \mathrm{O}_{5} 41.44 \mathrm{~kg} \mathrm{ha}^{-1}$ and Exchangeable 
$\mathrm{K} 366.51 \mathrm{~kg} \mathrm{ha}^{-1}$. The yield components were taken as the number of red fruits harvested from five plants counted and the total weight of fruits harvested in each picking was computed, averaged and expressed in weight per plant in grams. Five fruits selected for determining the fruit weight where used for determining the fruit length and girth averaged and expressed in centimeters. The total fruits harvested in each pickings of the treatment was computed and expressed as the weight of fruit in $\mathrm{kg} \mathrm{bed}^{-1}$ and converted as $\mathrm{t} \mathrm{ha}^{-1}$ (dry fruits). Nutrient uptake in plants parts at harvest worked out using following formula.

Uptake $\left(\mathrm{kg} \mathrm{ha}^{-1}\right)=$

$\%$ nutrient concentration $\mathrm{x}$ dry matter $\left(\mathrm{kg} \mathrm{ha}^{-1}\right)$

100

\section{Results and Discussion}

\section{Effect on yield and yield components}

A glance look of Table 1 revealed that the application of different fertilizers sources and mulching under drip fertigation has significantly influenced the yield and yield components of red Chilli compared to nonmulch treatments and control. The yield attributes like no. of fruits per plant (142), fruit length $(11.13 \mathrm{~cm})$, fruit girth $(4.75 \mathrm{~cm})$, red fruit weight $(1.29 \mathrm{~g})$, fruit yield per plant (184.11) and dry fruit yield (5.03 $\left.\mathrm{t} \mathrm{ha}^{-1}\right)$ was recorded in the treatment $T_{1}$ receiving $100 \%$ RDF through fertigation with water soluble fertilizers and polyethylene mulching followed by $\mathrm{T}_{5}, \mathrm{~T}_{7}$ and $\mathrm{T}_{2}$ respectively. While nonmulch treatments and soil application control yield of chilli was found to be a nonsignificant. From this results yield of chilli responded well to fertigation along with mulching combinations. This might be due to the better uptake of nutrients from the soil and higher availability of soil moisture. Fertigation with mulching resulted in to lower losses of nutrient owing to fixation, low leaching and less through runoff, which helped in establishing the roots, initiating more fruiting points, their subsequent retention and development in the plant leading to the higher number of fruits per plant, yield and other parameters as compared to conventional fertilizer application.

Similar findings were reported by Sajjan (2000), Prabhakar et al., (2010) and Ramachandrappa et al., (2010) in green chilli. Manohar (2002) in capsicum, Krishnamoorthy and Noorjehan (2014), Leela Rani et al., (2015) in chilli.

\section{Effect on uptake of nutrients by chilli}

The data pertaining to the uptake of $\mathrm{N}, \mathrm{P}, \mathrm{K}$ different treatments are showed in the Table 2. The results significantly showed that higher uptake of nitrogen $\left(148.01 \mathrm{~kg} \mathrm{ha}^{-1}\right)$ in chilli crop were recorded with treatment $\mathrm{T}_{1}$ WSF fertization $100 \%$ RDF with mulching which was on par with $\mathrm{T}_{5}\left(140.28 \mathrm{kgha}^{-1}\right)$ fertigation $100 \%$ RDF with mulching as compared to rest of the treatments. Significantly lower total nitrogen uptake was recorded in $\mathrm{T}_{9}(67.69 \mathrm{~kg}$ $\mathrm{ha}^{-1}$ ) soil application $100 \% \mathrm{RDF}$ without mulching. Significant increase total nitrogen uptake by chilli crop with application of RDF through fertigation with mulching over control may be due to continuous availability of nitrogen and uniform availability of soil moisture than in rest of the treatments. Similar observations were made by Kadam et al., (2005), Deepadevi and Shanth (2013) in tomato and Tipu et al., (2014) in chilli. From this perusal of the data on the maximum total p uptake (23.80, 22.74 and $20.29 \mathrm{~kg} \mathrm{ha}^{-1}$ ) were recorded in the treatment of $\mathrm{T}_{1}, \mathrm{~T}_{5}, \mathrm{~T}_{2}$ respectively and which significantly superior over control. The increased uptake of $\mathrm{P}$ might be ascribing more availability as well as continue application of fertilizers. Bagal (2009) showed increase in phosphorus uptake due to regular application of fertilizers. 
Table.1 Effect of fertigation and mulching on yield and yield characters of hybrid chilli

\begin{tabular}{|c|c|c|c|c|c|c|}
\hline Treatments & $\begin{array}{c}\text { No of fruits } \\
\text { plant }^{-1}\end{array}$ & $\begin{array}{c}\text { Fruit length } \\
(\mathbf{c m})\end{array}$ & $\begin{array}{c}\text { Fruit } \\
\text { girth } \\
(\mathbf{c m})\end{array}$ & $\begin{array}{c}\text { Fruit } \\
\text { weight (g) }\end{array}$ & $\begin{array}{c}\text { Fruit yield } \\
\text { per plant }(\mathbf{g})\end{array}$ & $\begin{array}{c}\text { Fruit yield } \\
\text { t ha }^{-1}\end{array}$ \\
\hline T1 & 142.74 & 11.13 & 4.75 & 1.29 & 184.11 & 5.03 \\
\hline T2 & 139.07 & 10.60 & 4.53 & 1.24 & 172.49 & 4.72 \\
\hline T3 & 129.66 & 9.77 & 4.46 & 1.16 & 150.39 & 4.46 \\
\hline T4 & 126.32 & 9.52 & 4.29 & 1.09 & 137.62 & 4.28 \\
\hline T5 & 142.20 & 10.77 & 4.50 & 1.29 & 183.46 & 4.84 \\
\hline T6 & 125.57 & 9.56 & 4.29 & 1.14 & 143.44 & 4.23 \\
\hline T7 & 140.68 & 10.58 & 4.46 & 1.25 & 175.84 & 4.81 \\
\hline T8 & 122.43 & 9.34 & 4.22 & 1.12 & 137.12 & 4.22 \\
\hline T9 & 106.83 & 8.36 & 3.95 & 1.08 & 115.36 & 3.30 \\
\hline S. EM & 1.14 & 0.54 & 0.07 & 0.06 & 2.64 & 0.11 \\
\hline C. D. at 5 \% & 4.22 & 0.70 & 0.20 & 0.17 & 7.9 & 0.32 \\
\hline
\end{tabular}

Table.2 Effect of fertigation and mulching on N, P and K Nutrient uptake in hybrid chilli

\begin{tabular}{|c|c|c|c|}
\hline Treatments & $\begin{array}{c}\text { Nitrogen uptake } \\
\left(\mathrm{kg} \mathrm{ha}^{-1}\right)\end{array}$ & $\begin{array}{c}\text { Phosphorus uptake } \\
\left(\mathrm{kg} \mathrm{ha}^{-1}\right)\end{array}$ & $\begin{array}{c}\text { Potassium uptake } \\
\left(\mathrm{kg} \mathrm{ha}^{-1}\right)\end{array}$ \\
\hline T1 & 148.01 & 23.80 & 290.5 \\
\hline T2 & 134.36 & 20.29 & 274.9 \\
\hline T3 & 109.80 & 14.21 & 251.3 \\
\hline T4 & 91.67 & 10.50 & 235.2 \\
\hline T5 & 140.28 & 22.74 & 286.4 \\
\hline T6 & 107.5 & 13.30 & 265.4 \\
\hline T7 & 136.99 & 11.24 & 285.1 \\
\hline T8 & 103.85 & 6.12 & 232.1 \\
\hline T9 & 67.69 & 2.31 & 184.3 \\
\hline S. EM \pm & 2.96 & 1.49 & 8.06 \\
\hline C. D. at 5 \% & 8.89 & 4.46 & 24.16 \\
\hline
\end{tabular}

Whereas the significantly highest $(290.5 \mathrm{~kg}$ $\mathrm{ha}^{-1}$ ) uptake of $\mathrm{K}$ was recorded in the treatment $\mathrm{T}_{1}$ and which was found at par with $\mathrm{T}_{5}, \mathrm{~T}_{7}$ and $\mathrm{T}_{2}$. Application of fertilizers through fertigation with mulching recorded significantly higher $\mathrm{K}$ uptake than soil application form, which was opined by Kadam (2005). The results showed that fertigation with water-soluble fertilizers and normal fertilizers produced on par results. Similarly, 100 and 75 per cent of recommended dosage of water-soluble fertilizer and NK fertigation (P soil application) also recorded on par results with $100 \%$ WSF fertigation. Cost on watersoluble fertilizer can be reduced by normal fertilizer application, 75\% RDF fertigation or NK fertigation. Overall fertigation and polyethylene mulching produced higher yield and total NPK nutrient uptake compared to soil application and nonmulching. This may be due to better availability of nutrients and moisture to the plant to enter in to reproductive phase early and enhances the crop yields. 


\section{References}

Bagal, M. D. 2009. Efficacy of fertilizers containing nitrogen, phosphorus, potassium on yield, nutrient uptake by rice (oryza sativa) and soil properties. M.Sc. (Agri.) Thesis Dr. B. S. K. K.V., Dapoli. India.

Chandini raj, A., Holebasappa, K. Hore, J.K. and Chattopadya, N. 2016. Growth and yield of chilli (Capsicum annuиm L.) as influenced by different growth regulators. The Bioscan, 11(1): 385388.

Deepa Devi, N. and shanthi, A. 2013. Effect of foliar spray of water soluble fertilizer on growth and NPK uptake of chilli hybrid (Capsicum annuиm L.) The Asian J. Hort., 8(1): 222-225.

Hatami, S., Nourjou, A., Henareh, M. and Pourakbar, I. 2012. Comparison effects of different methods of block plastic mulching and plastic mulching and planting pattern on weed control, water use efficiency and yield in tomato crops. Int. J. Agric. Sci., 2: 928-934.

Kadam, J. R., Karthikeyan, S. and Walke, V. N. 2005. Uptake of nutrient as influenced by soluble N, P and $\mathrm{K}$ fertilizers applied through drip irrigation for tomato. Ann. Pl. Physiol. 19(1): 80-84.

Krishnamoorthy, V. and Noorjehan, A. K. 2014. Effect of water soluble and conventional fertilizers on growth and yield of chillies. J. Krishi Vigyan., 2(2): 28-30.

Leela rani, P., Balaswamy, Ramachandra rao, K. A. and Masthan, S. C. 2015.
Evaluation of integrated nutrient management practices on growth, yield and economics of green chilli cv. Pusa Jwala (Capsicum annuum L.). Int. J. of Bio-resource and Stress Management., 6(1): 076-080.

Manohar, K.R. 2002. Evolution of capsicum (Capsicum annum) genotypes and effect of source of fertilizers and levels of fertigation under cost effective green house. Ph.D (Agri.). Hort., Thesis Univ. Agri. sci., Bangalore.

Prabhakar, B.N., Ramachandrappa, B.K., Nanjappa, H.V. and Soumya, T.M. 2010. Effect of frequency and methods of fertigation on growth, yield, quality and economics of green chilli (Capsicum аппиит L.). Mysore J. Agric. Sci., 44(3): 523-528.

Ramachandrappa, B.K., Nanjappa, H.V, Prabhakar, B. N. and Soumya, T.M. 2010. Effect of sources and level of fertilizer for drip fertigation on crop productivity, rooting and fertilizer use efficiency in green chilli (Capsicum аппиит L.). Mysore J. Agril. Sci., 44(2): 345-349.

Sajjan, M. 2000. Effect of nitrogenous and phosphatic bio fertilizers on growth, yield and quality of chilli (Capsicum апnиит) Cv. Byadagi Dabbi. M.Sc (Agri) in Horti., Thesis Univ. Agri. Sci., Bangalore.

Tipu, M.M.H., Amin, M., Dhar, M. and Alam, M. A. 2014. Effects of mulching on yield and quality of tomato varieties research and reviews. J. Agric. Sci. Tech., 3(3): 12-1.

\section{How to cite this article:}

Chandramohan Reddy, G., S.S. Hebbar, A.K. Nair, H.B. Raghupathy, A.P. Mallikarjuna Gowda and Umesha, K. 2018. Impact of Mulching and Sources of Fertilizer on Yield and Nutrient Uptake in Red Chilli (Capsicum annuum L.) under Drip Irrigation. Int.J.Curr.Microbiol.App.Sci. 7(01): 1542-1546. doi: https://doi.org/10.20546/ijcmas.2018.701.187 